\title{
USE OF SEMI-CONDUCTING BISMUTH SULFIDE AS A PHOTOCATALYST FOR DEGRADATION OF ROSE BENGAL
}

\author{
Shweta Sharma ${ }^{a}$, Rakshit Ameta ${ }^{\text {, }}$ R. K. Malkania, Suresh C. Ameta ${ }^{a *}$ \\ ${ }^{a}$ Department of Chemistry, M. L. Sukhadia University, Udaipur-313002 India \\ ${ }^{\mathrm{b}}$ Department of Pure and Applied Chemistry, University of Kota, Kota - 324005 India \\ *ameta_sc@yahoo.com,rakshit_ameta@yahoo.in
}

\begin{abstract}
Different methods have been adopted for the removal and degradation of dyes from effluents of textile, dyeing and printing industries. These methods have their own merits and drawbacks. In the present investigation, bismuth sulfide has been used as a photocatalyst for the degradation of rose Bengal. The effect of different parameters like the $\mathrm{pH}$, concentration of dye solution, amount of semiconductor and light intensity on the rate of reaction has been investigated. The reaction follows pseudo-first order kinetics. The optimum conditions were obtained as: [rose Bengal] $=1.60 \cdot 10^{-5} \mathrm{M} ; \mathrm{Bi}_{2} \mathrm{~S}_{3}=0.10 \mathrm{~g} ; \mathrm{pH}=$ 8.5 , and light intensity $=50.0 \mathrm{~mW} \cdot \mathrm{cm}^{-2}$. The rate constant was $4.68 \cdot 10^{-5} \mathrm{sec}^{-1}$. A mechanism has been proposed for the degradation of rose Bengal involving hydroxyl radicals.
\end{abstract}

Keywords: semiconductor; photocatalyst; rose Bengal; hydroxyl radical; bismuth sulphide

\section{УПОТРЕБА НА ПОЛУСПРОВОДНИЧКИ БИЗМУТ-СУЛФИД КАКО ФОТОКАТАЛИЗАТОР ЗА РАСПАЃАњЕ НА БЕНГАЛСКО РОЗОВО}

Приспособени се различни методи за отстранување и распаѓање на бои од ефлуентите во индустриите за текстил, бои и печат. Таквите методи имаат свои предности и недостатоци. Во оваа студија бизмут-сулфид е користен како фотокатализатор за распаѓ⿱ање на бенгалско розово. Следен е ефектот на различните параметри - $\mathrm{pH}$, концентрацијата на раствор од боја, количеството на полуспроводник и интензитетот на светлина, врз брзината на реакција. Реакцијата се покорува на кинетика од псевдо-прв ред. Најдени се следните оптимални услови: бенгалско розово $=1,60 \cdot 10^{-5}$ $\mathrm{M} ; \mathrm{Bi}_{2} \mathrm{~S}_{3}=0,10 \mathrm{~g} ; \mathrm{pH}=8,5$ и интензитет на светлина $=50,0 \mathrm{~mW} \cdot \mathrm{cm}^{-2}$. Константата на брзина изнесува $4,68 \cdot 10^{-5} \mathrm{~s}^{-1}$. Предложен е механизам за распаѓање на бенгалско розово кој вклучува хидроксилни радикали.

Клучни зборови: полуспроводник; фотокатализатор; бенгалско розово; хирдоксилен радикал; бизмут-сулфид 


\section{INTRODUCTION}

The entire world is facing the problem of pollution in its different forms and water pollution is one of the major constituent. In the present time of industrialization, a number of the effluents are discharged in the resources of water without any treatment, which creates water pollution. Different textile, dyeing and printing industries also discharge the coloured water in their nearby water resources without any treatment. This coloured water is quite harmful and also, sometimes, toxic in nature. Different methods are being used for the removal of the coloured dye, but in most of them, the process of adsorption has been used.

Researchers have used different oxides and sulphides-based semiconductors as photocatalyst for destroying dyes. For example, Hidaka [1] studied the photodegradation of surfactants on $\mathrm{TiO}_{2}$ semiconductor from waste water; while photocatalytic removal and recovery of mercury from water using $\mathrm{TiO}_{2}$ modified sewage sludge carbon has been investigated by Zhang et al. [2]. Photodegradation of methylene blue using sunlight and $\mathrm{TiO}_{2}$ was investigated by Nogueria and Jardin [3]. Photodegradation of lignin from black liquor using a UV/ $\mathrm{TiO}_{2}$ system was investigated by Ksibi et al. [4]. Karunakaran and Senthilvelan [5] introduced $\mathrm{CdO}$ as a photocatalyst for the oxidation of aniline to azobenzene, while photodegradation of squarylim cyanine dye under visible light irradiation was studied by $\mathrm{Wu}$ et al. [6].

Photocatalytic reaction of environmental pollutants $\mathrm{Cr}(\mathrm{VI})$ over $\mathrm{CdS}$ powder was observed by Wang et al. [7]. Photocatalytic activity of antimony(III) sulphide in bleaching of Azure-B was carried out by Ameta et al. [8]. Photoreduction of Congo red by ascorbic acid and EDTA over cadmium sulphide as photocatalyst was carried out by Kothari et al. [9]. Ameta et al. [10] used semi-conducting iron(III) oxide as photocatalyst for bleaching of methylene blue, crystal violet and malachite green dyes. Li et al. [11] reported photoelectrocatalytic oxidation of rose Bengal in aqueous solution using a $\mathrm{Ti} / \mathrm{TiO}_{2}$ mesh electrode. Biodegradation of rose Bengal by Phanerochaete chrysosporium was carried out by Gogna et al. [12]. Photoelectrocatalytic degradation of rose Bengal has been carried out by Liu et al. [13]. Bleaching products of rose Bengal under reducing condition were studied by Zakrzewski and Neckers [14], and the photocatalytic reduction of the dye methylene blue by $\mathrm{Bi}_{2} \mathrm{~S}_{3} / \mathrm{CdS}$ nanocomposites was carried out by Kobasa and Tarasenko [15]. As can be seen by these various degradation reactions of dyes, so far no work has been carried out with bismuth sulfide as photocatalyst.

In the present work we have carried out a kinetic and mechanistic study of the degradation of rose Bengal using a semi-conducting bismuth sulfide as a photocatalyst.

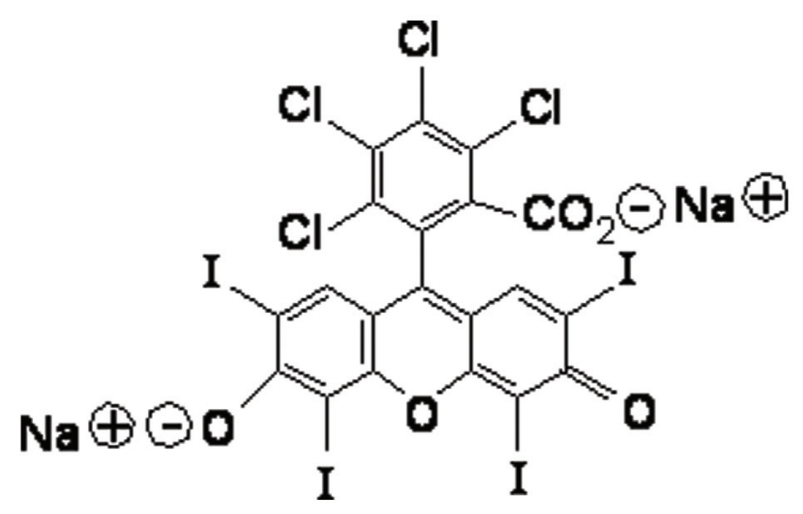

Structure of rose Bengal

\section{EXPERIMENTAL}

$1.0 \cdot 10^{-3} \mathrm{M}$ rose Bengal solution was prepared in doubly distilled water and used as a stock solution. This stock solution was further diluted with doubly distilled water, as and when required.

The optical density (OD) of rose Bengal solutions was determined with a spectrophotometer (Systronics Model 106) at $\lambda_{\text {max }}=550 \mathrm{~nm}$.

The solutions of rose Bengal were placed in equal amounts in four beakers.

- The first beaker containing rose Bengal solution was kept in dark. 
- The second beaker containing rose Bengal solution was exposed to light.

- The third beaker containing rose Bengal solution and $0.10 \mathrm{~g}$ bismuth trisulphide was kept in dark.

- The fourth beaker containing rose Bengal solution and $0.10 \mathrm{~g}$ bismuth trisulphide was exposed to light.

After keeping these beakers for four hours, the optical density of the solution in each beaker was measured. It was found that the optical density (OD) of solutions of the first three beakers remained almost constant, while the OD initial value of the solution of the fourth beaker decreased. From these observations, it was clear that this reaction required the presence of both; the light as well as semiconductor bismuth trisulphide. Hence, this reaction is a photocatalytic reaction and not chemical and / or photochemical.

A solution of rose Bengal $\left(1.60 \cdot 10^{-5}\right.$ M) was prepared in doubly distilled water, and $0.10 \mathrm{~g}$ of bismuth trisulphide was added to it. The $\mathrm{pH}$ of the reaction mixture was adjusted to 8.5. Then the solution was exposed to a $200 \mathrm{~W}$ tungsten lamp. An aliquot of $2.0 \mathrm{ml}$ was taken out from the reaction mixture and its OD was measured at $550 \mathrm{~nm}$ at regular time intervals. All kinetic measurements were performed at a temperature $30 \pm 0.1^{\circ} \mathrm{C}$.

\section{RESULTS AND DISCUSSION}

It was observed that the rose Bengal aqueous solution OD decreased with increasing time of exposure. A graphical plot of log OD against time was found to be linear (Figure 1). The rate constant obtained was $4.68 \cdot 10^{-5} \mathrm{sec}^{-1}$.

\subsection{Effect of $p H$}

The $\mathrm{pH}$ of the solution is likely to affect the degradation of the rose Bengal and hence, the effect of $\mathrm{pH}$ on the rate constant of degradation of rose Bengal was investigated in the $\mathrm{pH}$ range

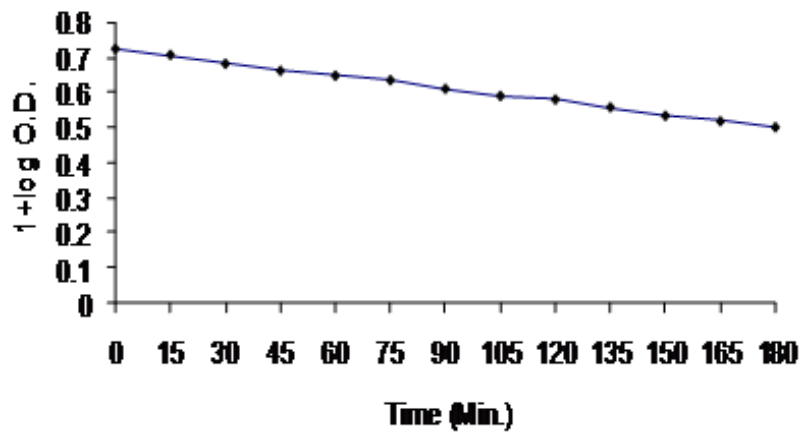

Fig. 1. A typical kinetic run of the rose Bengal photo-catalyzed degradation,

$\mathrm{pH}=8.5$, [rose Bengal $]=1.60 \cdot 10^{-5} \mathrm{M}, \mathrm{Bi}_{2} \mathrm{~S}_{3}=0.10$ $\mathrm{g}$, light intensity $=50.0 \mathrm{~mW} \cdot \mathrm{cm}^{-2}$

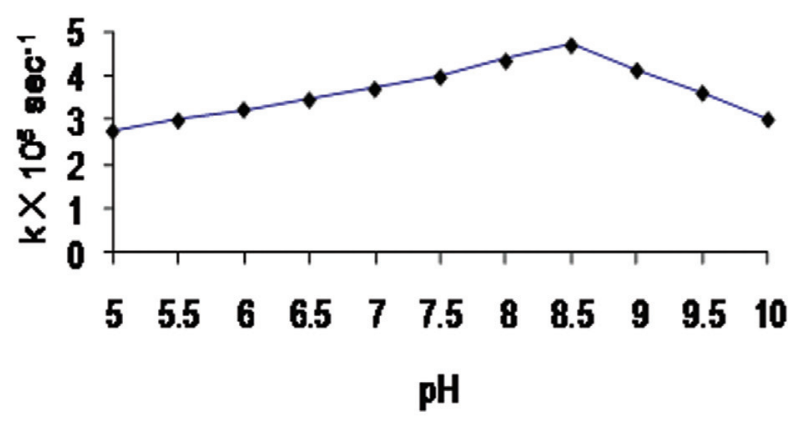

Fig. 2. Effect of $\mathrm{pH}$ on the rate constant of rose Bengal photo-catalyzed degradation $\mathrm{pH}=8.5$, [rose Bengal $]=1.60 \cdot 10^{-5} \mathrm{M}$, $\mathrm{Bi}_{2} \mathrm{~S}_{3}=0.10 \mathrm{~g}$, light intensity $=50.0 \mathrm{~mW} \cdot \mathrm{cm}^{-2}$

$5.0-10.0$. The results are reported in Figure 2.

It is evident that the rate of photocatalytic degradation of rose Bengal increases with $\mathrm{pH}$. The increase in the rate of photocatalytic degradation may be due to the greater availability of $\mathrm{OH}^{-}$ions at higher $\mathrm{pH}$ values. More $\mathrm{OH}$ radicals are generated by the abstraction of an electron by the hole of the semi-conductor from $\mathrm{OH}^{-}$ions. These hydroxyl radicals are considered responsible for the photocatalytic degradation. But after a certain value of $\mathrm{pH}$, i.e. 8.5, a further increase in $\mathrm{pH}$ of the medium decreases the rate of photocatalytic degradation. It may be due to the fact that rose Bengal remains in its anionic form at higher $\mathrm{pH}$ and, therefore these anionic species of rose Bengal will face a force of repulsion with 
negatively-charged semiconductor surface. As a consequence, the reaction rate decreases.

\subsection{Effect of dye concentration}

The effect of variation of dye concentration on the rate of the reaction was studied by taking different concentrations of rose Bengal. The results are provided in Table 1 .

Table 1

\begin{tabular}{|c|c|}
\hline$\left[\right.$ Rose Bengal] $\cdot 10^{5} \mathrm{M}$ & $k \cdot 10^{5}\left(\mathrm{~s}^{-1}\right)$ \\
\hline 0.80 & 2.10 \\
\hline 1.00 & 2.99 \\
\hline 1.20 & 3.48 \\
\hline 1.40 & 4.16 \\
\hline 1.60 & 4.68 \\
\hline 1.80 & 4.21 \\
\hline 2.00 & 3.76 \\
\hline 2.20 & 3.27 \\
\hline
\end{tabular}

It has been observed, that the rate of photocatalytic degradation increases with an increase in the concentration of the rose Bengal. It may be due to the fact that as the concentration of rose Bengal was increased, more dye molecules were available for excitation and energy transfer and hence, an increase in the rate of degradation was observed. The rate of photocatalytic degradation was found to decrease with a further increase in the concentration of the dye. This may be attributed to the fact that, at a certain rose Bengal concentration, the dye molecules started acting as a filter for the incident light, which did not permit the desired light intensity to reach the semiconductor particles, resulting in a decrease of the rose Bengal photocatalytic degradation rate.

\subsection{Effect of amount of semiconductor}

The amount of semiconductor is also likely to affect the process of dye degradation and hence, different amounts of photocatalyst were used. The results are reported in Table 2.

$\mathrm{T}$ a b 1 e 2

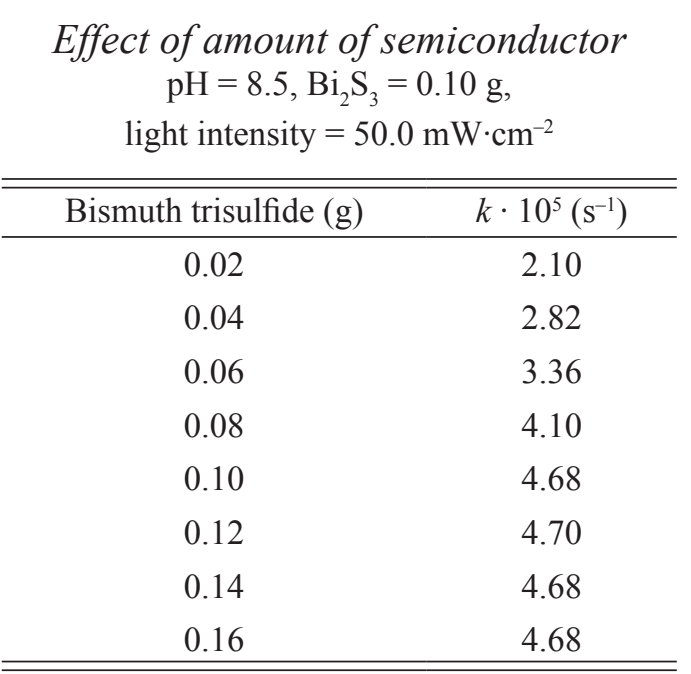

The rate of photodegradation of rose Bengal increases with an increase in the amount of semiconductor but ultimately, it becomes almost constant after a certain amount, i.e. 0.10 g. This may be attributed to the fact that as the amount of semiconductor was increased, the exposed surface area also increases, but after a certain limit, if the amount of semiconductor was further increased, then there will be no increase in the exposed surface area of the photocatalyst. It may be considered like a saturation point; above which, any increase in the amount of semiconductor has negligible or no effect on the rate of photocatalytic degradation of rose Bengal, as any increase in the amount of semiconductor after this saturation point will only increase the thickness of the layer at the bottom of the reaction vessel. The saturation point shifts to higher range for larger vessels, while reverse was true for smaller vessels. 


\subsection{Effect of light intensity}

To investigate the effect of light intensity on the photocatalytic degradation of rose Bengal, the distance between the light source and the exposed surface area was varied. The intensity of light was measured by Suryamapi (CEL Model SM 201) in terms of $\mathrm{mW} \cdot \mathrm{cm}^{-2}$. The results are summarized in Table 3.

It was observed that the rate of degradation increases as the intensity of light was increased, because any increase in the light intensity will increase the number of photons striking per unit area of semiconductor powder. An almost linear behaviour between light intensity and rate of reaction was observed. However, on increasing the intensity of light above $50.0 \mathrm{~mW} \cdot \mathrm{cm}^{-2}$, there was a decrease in the rate. This may be due to some side reactions.

Table 3

\begin{tabular}{cc}
$\begin{array}{c}\text { Effect of light intensity } \\
\mathrm{pH}=8.5, \mathrm{Bi}_{2} \mathrm{~S}_{3}=0.10 \mathrm{~g}, \\
\text { light intensity }=50.0 \mathrm{~mW} \cdot \mathrm{cm}^{-2}\end{array}$ \\
\hline $\begin{array}{c}\text { Intensity of Light } \\
\left(\mathrm{mW} \cdot \mathrm{cm}^{-2}\right)\end{array}$ & $k \cdot 10^{5}\left(\mathrm{~s}^{-1}\right)$ \\
\hline 10.0 & 1.48 \\
20.0 & 2.33 \\
30.0 & 3.24 \\
40.0 & 4.06 \\
50.0 & 4.68 \\
60.0 & 4.41 \\
70.0 & 4.03 \\
80.0 & 3.87 \\
\hline \hline
\end{tabular}

\subsection{Mechanism}

On the basis of these observations, the following, tentative mechanism for photocatalytic degradation of rose Bengal may be proposed:

$$
{ }^{1} \mathrm{RB}_{0} \stackrel{h v}{\longrightarrow}{ }^{1} \mathrm{RB}_{1}
$$

$$
\begin{gathered}
{ }^{1} \mathrm{RB}_{0} \stackrel{h v}{\longrightarrow}{ }^{1} \mathrm{RB}_{1} \\
\mathrm{SC} \stackrel{{ }^{h v}}{\longrightarrow} \mathrm{e}^{-}(\mathrm{CB})+\mathrm{h}^{+}(\mathrm{VB}) \\
\mathrm{h}^{+}+\mathrm{OH}^{-} \longrightarrow{ }^{\bullet} \mathrm{OH} \\
{ }^{3} \mathrm{RB}_{1}+{ }^{\cdot} \mathrm{OH} \longrightarrow \text { Leuco RB } \\
\text { Leuco } \mathrm{RB} \longrightarrow \text { Products }
\end{gathered}
$$

Rose Bengal (RB) absorbs radiations of suitable wavelength and gives rise to its excited singlet state. Then it undergoes intersystem crossing (ISC) to give the triplet state of the dye. The involvement of triplet state was confirmed by using triplet state scavengers, where the reaction rate was almost negligible. On the other hand, the semi-conducting bismuth trisulfide (SC) also utilizes the radiant energy to excite its electron from valence band to the conduction band; thus, leaving behind a hole. This hole abstracts an electron from $\mathrm{OH}^{-}$ions to generate - OH radicals. These radicals will oxidize the dye to its leuco form, which may ultimately degrade to products. The participation of $\cdot \mathrm{OH}$ radicals as an active oxidizing species was confirmed by using hydroxyl radical scavenger isopropanol, where the rate of bleaching was drastically reduced. The rate constant $k=1.06 \cdot 10^{-8} \mathrm{~s}^{-1}$ was observed in presence of hydroxyl radical scavenger isopropanol as compared to $k=$ $4.68 \cdot 10^{-5} \mathrm{~s}^{-1}$ in absence of isopropanol, which is almost 4500 times less than the original reaction rate.

\section{CONCLUSION}

Bismuth sulfide can be successfully used for the photocatalytic degradation of rose Bengal aqueous solution. The decolorized water can be used for some useful purposes like cleaning, cooling, irrigation etc. The photocatalysis is a promising technology for the treatment of waste waters and time is not far off, when this technology will be firmly established 
as an advanced oxidation process. It is also an eco-friendly technique to combat the problem of colored water effluents released by different textile, printing and dye industries.

\section{REFERENCES}

[1] H. Hidaka, Photodegradation of surfactants with $\mathrm{TiO}_{2}$ semiconductor for the environmental wastewater treatment, Proc. Indian Acad. Sci. (Chem. Sci.) 110, 215-228 (1998).

[2] F.S. Zhang, J. Nriagm, H. Itoh, Photocatalytic removal and recovery of mercury from water using $\mathrm{TiO}_{2}$ modified sewage sludge carbon, J. Photochem. Photobiol. 167A, 223-227 (2004).

[3] R.E.P. Nogueria, W.F. Jardin, Photodegradation of methylene blue using sunlight and $\mathrm{TiO}_{2}, J$. Chem. Educ. 70, 861-862 (1993).

[4] M. Ksibi, S. Ben-Amor, S. Cherif, E. Elaoui, A. Houas, M. Elaloui, Photodegradation of lignin from black liquor using a U.V./TiO 2 system, $J$. Photochem. Photobiol. 154A, 211-215 (2003).

[5] C. Karunakaran, S. Senthilvelan, Semiconductor catalysis of solar photooxidation, Curr. Sci. 18, 962-967 (2005).

[6] T. Wu, T. Un, J. Zhao, H. Hidaka, N. Serpone, Photodegradation of squarylium cyanine dye under visible light irradiation, Environ. Sci. Technol. 33, 1379-1387 (1999).

[7] S.S. Wang, Z.H. Wang, Q.X. Zhuang, Photocatalytic reaction of environmental pollutants $\mathrm{Cr}(\mathrm{VI})$ over CdS powder, Appl. Catal. 1, 257-270 (1992).
[8] R. Ameta, A. Pandey, P.B. Punjabi, S.C. Ameta, Photocatalytic activity of antimony (III) sulphide in bleaching of azure-B, Chem. Environ. Res. 14, 255-260 (2005).

[9] S. Kothari, R. Vyas, R. Ameta, P. B. Punjabi, Photoreduction of congo red by ascorbic acid and EDTA over cadmium sulphide as photocatalyst, Indian J. Chem. 44A, 2266-2269 (2005).

[10] R. Ameta, J. Vardia, P.B. Punjabi, Suresh C. Ameta, Use of semiconducting iron(III) oxide in photocatalytic bleaching of some dyes, Indian $J$. Chem. Tech. 13, 114-118 (2006) .

[11] X.Z. Li, H.L. Liu, P.T. Yue, Y.P. Sun, Photoelectrocatalytic oxidation of rose bengal using a Ti/TiO ${ }_{2}$ mesh electrode, Environ. Sci. Technol. 34, 4401-4406 (2000).

[12] E. Gogna, R. Vohra, P. Sharma, Biodegradation of rose bengal by Phanerochaete chrysosporium, Lett. Appl. Microbiol. 14, 58-60 (2008).

[13] H. Liu, D. Zhou, X. Li, Pi. Yue, Photoelectrocatalytic degradation of rose bengal, J. Environ. Sci. 15, 595599 (2003).

[14] A. Zakrzewski, D.C. Neckers, Bleaching products of rose bengal under reducing conditions, Tetrahedron 43, 4507-4512 (1987).

[15] I.M. Kobasa, G.P. Tarasenko, Photocatalysis of reduction of the dye methylene blue by $\mathrm{Bi}_{2} \mathrm{~S}_{3} / \mathrm{CdS}$ nanocomposites, Theor. Exp. Chem. 38, (2002), 255-258. 